\title{
Quotation of Russian references
}

Acta Palaeontologica Polonica 53 (2), 2008: 356-356 doi:http://dx.doi.org/10.4202/app.2008.0214

This is an open-access article distributed under the terms of the Creative Commons

Attribution License (for details please see creativecommons.org), which permits unrestricted use, distribution, and reproduction in any medium, provided the original author and source are credited.

For 